\title{
A MEZŐGAZDASÁG PRIVATIZÁCIÓJA A DÉL-DUNÁNTÚLI RÉGIÓBAN
}

\author{
(Privatisation of the Agriculture \\ in the Southern Transdanubian Region) \\ KOVÁCS TERÉZ
}

A mezốgazdaság privatizációja egyrészt a politikai rendszerváltás következtében elindult folyamat, másrészt az Európai Közösségbe való belépésünk elốtt a tulajdonviszonyok változásába illeszkedố folyamat. Az Európai Közösség országaiban a birtokstruktúrán belül a ,,családi farm" típusa a domináló. EK-tagságunk idejére a mezôgazdasági tulajdonviszonyokban a rendszerváltás elốtti állapothoz képest jelentốs változás fog beállni. A változás a magántulajdon arányának növekedésében nyilvánul meg. Ennek ellenére Magyarországon még sokáig magasabb lesz a nagybirtok aránya - új típusú szövetkezetek, részvénytársaságok formájában -, mint az EK tagországainak többségében. Jelen tanulmány a privatizáció eddig elért eredményeivel kíván foglalkozni a négy dunántúli megyében. A privatizációt a - birtokviszonyokat legjobban érintô - tsz-átalakulásokon és a kárpótlăs folyamatán kíséri végig. Ezen a helyen nem lesz szó az állami gazdaságokról, amelyek privatizációja éppen csak, hogy elkezdôdött. Elôzetesen azonban szükséges áttekinteni a Dél-Dunántúl mezôgazdaságának néhány sajátosságát.

\section{A mezögazdasággal kapcsolatos néhány fontosabb adat}

A mezõgazdaságban foglalkoztatottak száma drasztikusan csökken. 1990 óta mintegy 300-400 ezerrel kevesebben dolgoznak az ágazatban. Különösen 1992-ben a tsz-átalakulások idején volt nagy a munkaerõ-kibocsátás a mezõgazdaságból. A Dél-Dunántúlon a rendszerváltás elsố két évében egyharmaddal csökkent a mezôgazdaságban dolgozók száma (1. táblázat). A csökkenés Tolnában volt a legkisebb és Baranyában a legnagyobb. Foglalkoztatási szempontból a mezógazdaság Tolnában és Somogyban a legjelentốsebb, hiszen ott minden ötödik ember a mezógazdaságban keresi meg a kenyerét. Zalában minden hetedik, Baranyában pedig minden nyolcadik emberrôl lehet ugyanezt elmondani. 


\section{TÁBLÁZAT}

A foglalkoztatottak száma a mezógazdaságban, vadgazdálkodásban, erdôgazdálkodásban és halászatban (1992)

(Number of employment in agriculture, wild culture, forestry and fishing [1992])

\begin{tabular}{lcccc}
\hline Megyék & $\begin{array}{c}\text { Össz- } \\
\text { foglalkoztatottak } \\
\text { száma }\end{array}$ & \multicolumn{2}{c}{$\begin{array}{c}\text { Ebböl a } \\
\text { mezógazdaságban } \\
\text { dolgozók }\end{array}$} & $\begin{array}{c}1992 / 1990 \\
\text { változás } \\
\% \text {-ban }\end{array}$ \\
\cline { 3 - 4 } & száma & \%-ban & \\
\hline Baranya & 124710 & 15545 & 12,5 & 61,8 \\
Somogy & 93737 & 18474 & 19,7 & 63,3 \\
Tolna & 74417 & 15428 & 20,7 & 71,7 \\
Zala & 94700 & 13232 & 14,0 & 65,4 \\
\hline Dél-Dunántúl & 387564 & 62679 & 16,2 & 65,3 \\
\hline
\end{tabular}

Forrás: Megyei statisztikai évkönyvek, 1992. KSH, 1993.

A Dél-Dunántúl az ország összes földterületének 19,2 százalékát foglalja magába. Hasonló arányt képvisel a termôterület is $(19,8 \%)$. Az erdốterületek tekintetében vannak a legnagyobb különbségek a dél-dunántúli megyék között. Erdôterületben Zala és Somogy emelkedik ki, míg Tolna e tekintetben már az országos átlag alatti. A térségben összességében az erdôterület $10 \%-\mathrm{kal}$ az országos átlag felett van.

1992-ben a kertterület országosan az elôzó évinek mindössze 10 százalékát teszi ki, ez a drasztikus csökkenés a Dél-Dunántúlra is érvényes. A csökkenés oka a privatizáció megjelenése a mezốgazdaságban. Míg 1991-ig a magántulajdonban lévổ földparcellák kertként jelentek meg a statisztikában, addig 1992-tôl a korábbi ,kerttulajdonosok”" kárpótlás, részarány-tulajdonlás vagy adásvétel útján további földterületekhez jutottak. Ahol ez a folyamat lassabban halad - elsôsorban Zala megyében, de a Dél-Dunántúl nagy részén is -, ott a kertek aránya nagyobb.

Dél-Dunántúl megyéiben a mũvelési ágak összetétele eltérô. A legnyugatibb Zala megyében az erdô, a gyümölcsös, a szôlố és a gyep dominál azzal, hogy a szántóterület aránya nagyon alacsony. Zala tér el legjobban a múvelési ágak tekintetében a régió és az ország átlagától. Hozzá valamelyest hasonlít Somogy, viszont Baranya és Tolna földjei más szerkezetũ mũvelési ágakkal birmak. A két legjövedelmezôbb és legintenzívebb ágazatból, a szántóföldbôl és a szôlôbôl arányaiban Tolna megyében van a legtöbb, a többi kevésbé jövedelmezô és kevésbé intenzív mûvelési ág rovására.

A szántóföldi növénytermesztést illetôen a dél-dunántúli régiót egy keleti és egy nyugati részre lehet osztani. A keleti rész egész Tolna és Baranya megyét, valamint Somogynak a keleti, , Baranya feletti”' részét foglalja magába. Ebben a térségben minden szántóföldi növényfajta termesztésére kiváló, vagy legalábbis jó termôhelyi adottságok vannak. Ez alól a régió keleti felén belül csak, a Mecsek-Baranyai-hegyhát-Zselic 
háromszög a kivétel. A nyugati részen a szántóföldi növénytermesztéshez - helyenként egy-két nem nagy volumenben termesztett növényfajtát (pl. rozs, zab) leszámítva nincsenek kiváló termõhelyi adottságok.

\section{A tsz-határos mezôgazdasági tájkörzetek sajátosságai}

Az elmúlt évtizedekben országosan mintegy 82 mezôgazdasági tájkörzetrôl beszéltek, ezek közül 20 a dél-dunántúli régióban volt. 1991-ig a megyei statisztikai évkönyvekben még szerepeltek ezek a tájkörzetek. Az 1992-es évkönyvek közül a Dél-Dunántúlon már a zalaiban és a baranyaiban nem találhatók meg az ezek szerinti statisztikai adatok. Ez összefüggésbe hozható azzal a ténnyel, hogy a Földmũvelésügyi Minisztérium 1992 ben megjelentette ,,A tájgazdálkodás alapjai" c. dokumentumot. A korábbi mezógazdasági tájkörzeteket jobbára termôhelyi adottságok alapján és tsz-határosan húzták meg, amelyek a Dél-Dunántúlon is nagyon eltérổ nagyságú területeket foglaltak magukba. Különösen jellemzõ ez Somogyra, ahol megtalálható volt a régió legkisebb (Zselicség 15279 ha) és legnagyobb (Somogyi-homokvidék 93695 ha) földterületũ tájkörzete.

E tájkörzetek földjeinek minôsége között nagy eltérések voltak. A szántóterületek átlagos aranykorona értéke alapján öt kategóriába lettek besorolva: 14 aranykoronáig ,,nagyon rossznak", 14,1-17 aranykoronáig ,,rossz" földeknek tekintették ôket. Ezek a múltban és ma is kedvezôtlen adottságú térségeknek számítanak, melyek ismét támogatásért folyamodhatnak. Dél-Dunántúl 20 mezõgazdasági kistérségébõl 7 idesorolható.

Az 1. ábrán látható, hogy a legalacsonyabb aranykorona értékũ szántóföldek két „,foltban" találhatók. Az egyik a Mecsek-Zselic-Hegyhát és ez folytatódik Somogyban a Zselicség és a Somogyi-homokvidék körzeteiben. A másik alacsony aranykorona értékũ földterület a Zala megyei Göcsej-Hetés és az Zalai-dombság északi vidékét jellemzi.

A szántóterületek aránya ott a legmagasabb, ahol a legmagasabb aranykorona értékú földek vannak. Az erdôterületek szinte tükörképei a szántóknak és az aranykoron-értékeknek. A gyepterületekrôl ugyanez csak részben mondható el. Nyugat-Európában egyre elterjedtebb az a jelenség, hogy a területeket kivonják a mũvelés alól és a természetnek adják vissza (natural development area). Ezáltal növelni kívánják a turizmust, és csökkenteni a túltermelési válságból eredô problémákat. Valószínũ, hogy nálunk is hasonló folyamatra kerül sor és elôször itt is a gyepterületeket vonják ki a mũvelés alól. E tekintetben a régió szempontjából hátrány az, hogy Zalaegerszeget kivéve a három másik megyeszékhely olyan térségben helyezkedik el, ahol a legkisebb a gyepterületek aránya, holott várhatóan a nagy- és középvároși lakosság részérõl merül fel elôször a természetnek visszaadott térségek használata iránti igény. 
Kovács Teréz: A mezőgazdaság privatizációja a dél-dunántúli régióban.

Tér és Társadalom, 8. 1994. 1-2. 109-128. p.

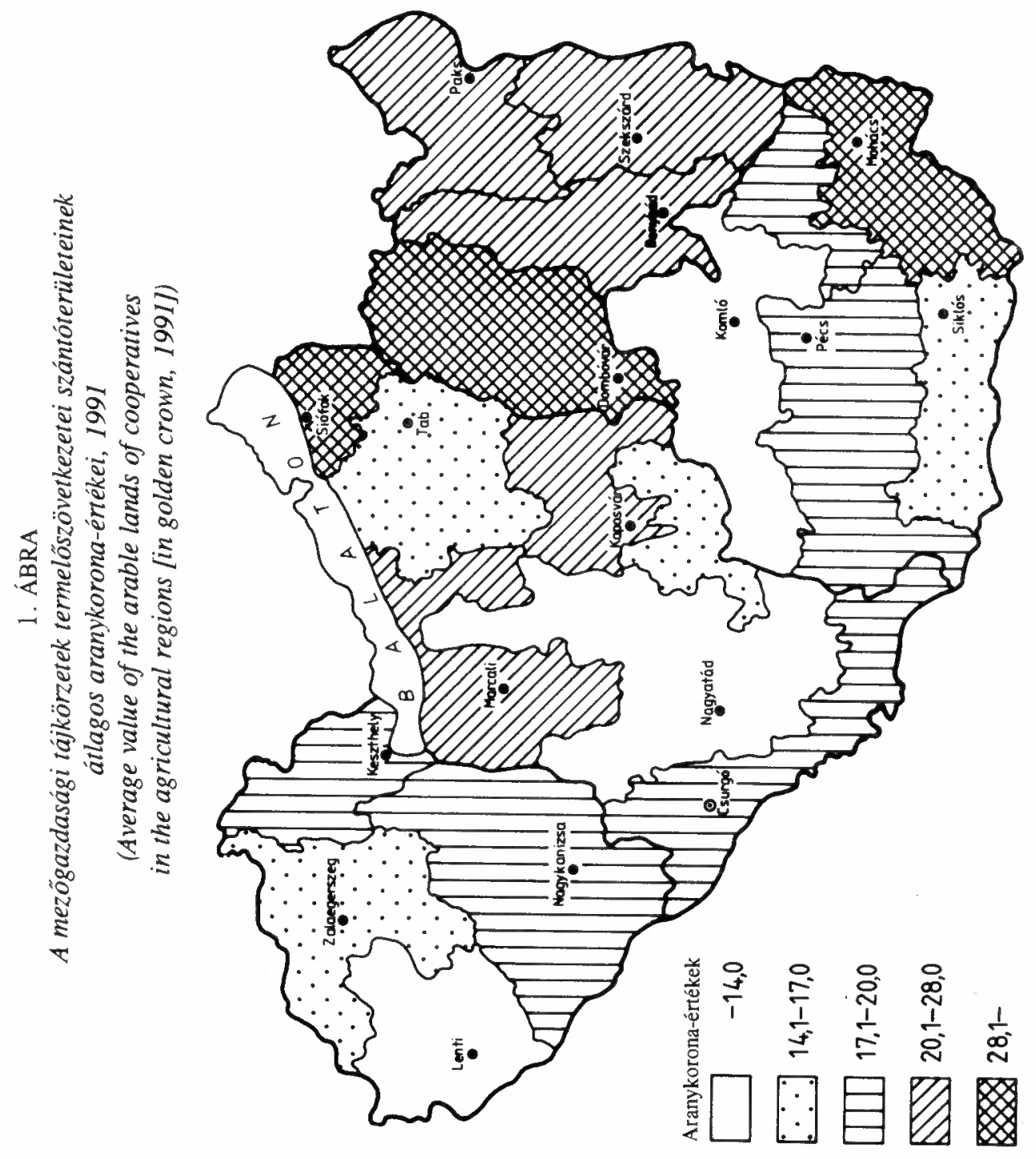


Az FM ,,A tájgazdálkodás alapjai" címũ dokumentumban indokoltnak tartja országosan mintegy 0,8 millió hektár kedvezôtlen adottságú szántó és gyep erdôsítését és 0,2 millió hektár kedvezôtlen adottságú szántó gyepesítését. Ezzel a szántóföldi mũvelés 42 százalékra csökkenne, a rét, legelô aránya $13 \%$-ról $14 \%$-ra, az erdốké pedig $18 \%$-ról $27 \%$-ra emelkedne. ${ }^{1}$

\section{A szövetkezeti vagyon felosztása}

A szövetkezeti vagyon privatizációjánál különbséget kell tenni a föld és az egyéb vagyoni tárgyak privatizációja között.

A 2. táblázatból látható, hogy a tsz-vagyon felosztása elốtt az egy fốre jutó saját vagyon igencsak eltérố értékeket mutatott. ${ }^{2}$ A két véglet Baranyában található. A Mecsek-Zselic-Hegyhát térségében a tagok elvben átlagosan csak 304 ezer forintot oszthattak volna szét, míg a Baranyai-lösz-szigeten ez az összeg 753 ezer forintot tett ki. A vagyon nemcsak a tagok, hanem a kívülállók között is szétosztásra került, ami módosította, azaz csökkentette a ténylegesen egy fốre jutó részt.

A régióban a legtốkeszegényebbek a Somogy megyei tsz-ek voltak. Tôkeszegénységük fố oka az, hogy a Magyar Nemzeti Bank Somogy Megyei Igazgatósága az 1960-as években szigorú beruházási politikát folytatott, amelynek következtében kevés hitelt adtak a szövetkezeteknek (mint köztudott, az akkori hitelek jelentõs részét 1967-ben elengedték). A megye tsz-ei egykori lemaradásukat, illetve hátrányukat a késõbbiekben sohasem tudták bepótolni. Tolnában Somoggyal szemben nem voltak nagy különbségek a mezôgazdasági mikrokörzetek között az egy tsz-tagra jutó vagyon tekintetében. Emellett az aktív tagok aránya Tolnában átlagosan tíz, Baranyában három százalékkal az országos átlag felett volt, mig Somogyban négy, Zalában meg három százalékkal az országos átlag alatt maradt.

A szövetkezeti átalakulás során a föld értéke nélküli közös vagyont forintban nevesítették, majd a nevesitett vagyont törvény alapján részjegy és üzletrész formájában osztották szét az érintettek között. A vagyonnak lényegesen kisebb része került részjegy formájában szétosztásra, mert a törvény szerint a részjegyek értékének összege egy tszen belül nem lehet több a vagyon tíz százalékánál.

A részjegyeknek forintfedezete van, amihez csak a tagok juthattak hozzá. Termelöszövetkezetenként nagyon eltérõ összegekben határozták meg a részjegy nagyságát. (Országosan $21000 \mathrm{Ft} /$ fố, Baranyában $23000 \mathrm{Ft} /$ fô, Zalában csak $14000 \mathrm{Ft} /$ fô volt az értéke.) Kilépés esetén a tagnak ezt az összeget ki kell fizetnie, míg az új belépönek az alapszabály szerint - ahhoz, hogy tag lehessen, kötelessége ezt az összeget befizetni. A részjegy tehát a ma ott dolgozók érdekeit hivatott védeni a jövôben belépó új tagokkal szemben. 
Kovács Teréz: A mezőgazdaság privatizációja a dél-dunántúli régióban.

Tér és Társadalom, 8. 1994. 1-2. 109-128. p.

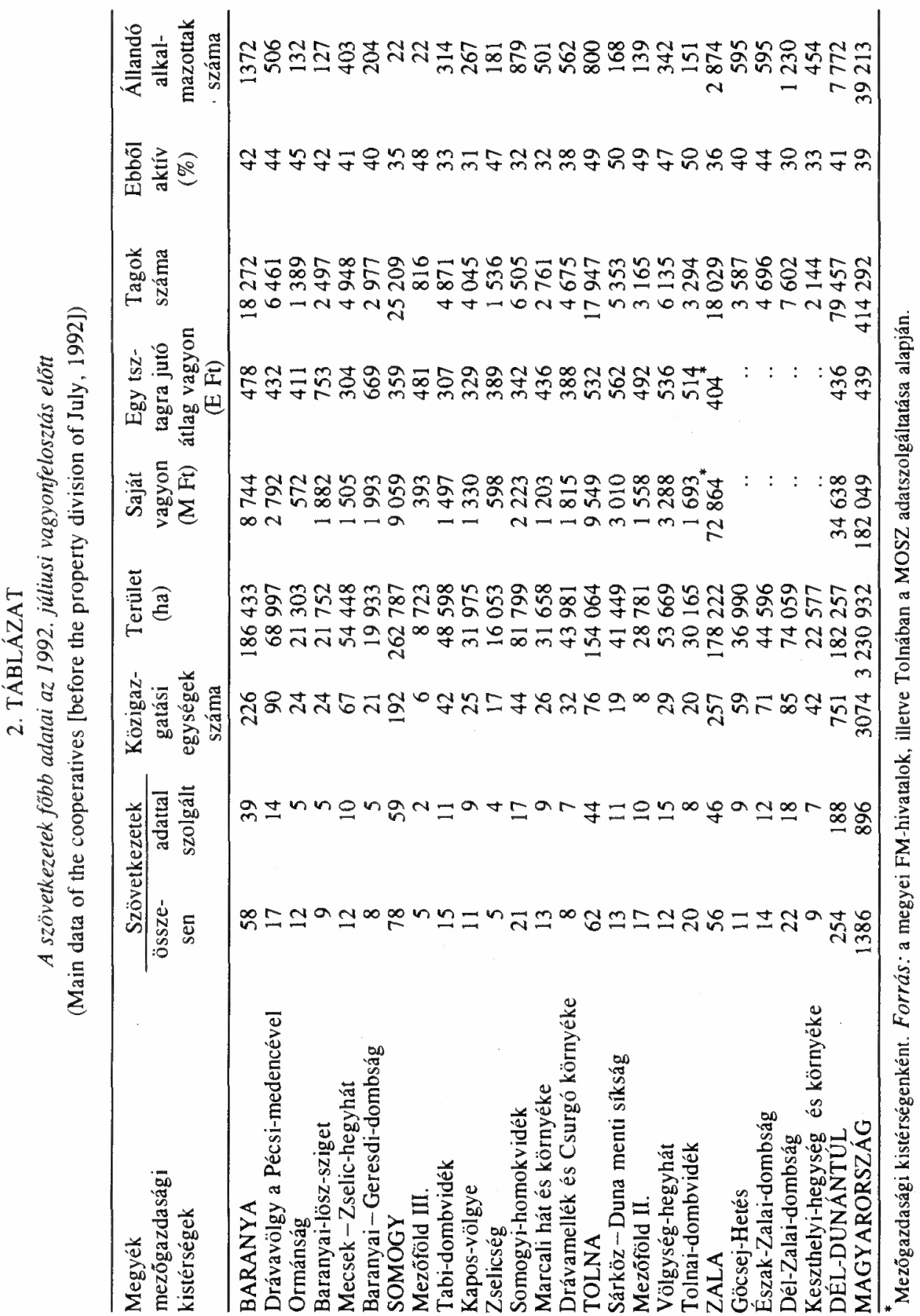


A nevesített vagyon nagyobb része üzletrész formájában került az érintettek között szétosztásra. Az üzletrésznek nem forint, hanem egyéb eszközfedezete van. Továbbá az üzletrész-szerzésre nemcsak az aktív és nyugdijas szövetkezeti tagok jogosultak, hanem az ún. kívülállók is, azaz azok az egykori tagok, illetve leszármazottaik, akik legalább öt évet dolgoztak a tsz-ben. Helyenként a ma ott dolgozó alkalmazottak is részesültek a vagyonjuttatásból. A 3. táblázat a szövetkezetek vagyonának megoszlását mutatja (országos adatok). Majd a következö négy táblázatban Baranya, Somogy, Zala és Tolna megye hasonló adatai találhatók.

Az aktív tagok, a nyugdíjasok és a kívülállók közötti vagyonmegoszlás mezôgazdasági tájkörzetenként igen eltérô volt. Ez a 2. ábrán látható. (Az alkalmazottak üzletrésze - az elemzés során - össze van vonva az aktív szövetkezeti tagok üzletrészével.) Baranyában minden tájkörzetben a tsz-vagyon több mint fele az aktív tagok kezébe került, a kívülállók vagyona sehol sem éri el az összvagyon egyötödét, ezzel szemben a Balatonnal határos mezõgazdasági mikrorégiókban a kívülállók mindenütt megszerezték a tsz-vagyon több mint egyötödét. A nyugdíjasok a tolnai Mezőföldön, továbbá Zala, de fớleg Somogy minden egyes tájkörzetében több vagyonhoz jutottak, mint az aktív tagok, ami egyfelôl a vagyonfelosztási politikából, másfelốl a tagság korösszetételébôl adódik.

A vagyonfelosztás után zajlottak le a tsz-böl való kiválások. A dél-dunántúli régióban nagyobb kiválások, szétválások nem történtek. A tsz-szétválások Baranya és Tolna három-három tsz-központját érintették, mégpedig azokat, ahol a német nemzetiségiek aránya a legmagasabb volt: a Mohács és Bonyhád környéki kisebb települések tsz-eit. Zalában csak egy, Somogyban pedig kilenc, településenkénti szétválás volt. Somogyban e szétválások helyenként nagy virtusok között zajlottak le. Elôfordult, hogy a falu egykori módosabb gazdái, illetve azok leszármazottai váltak el a tagság többi részétôl. A német lakosú falvak (pl. Ráksi) ebben a megyében is önállósultak. Ha egy falu ,,elindult kifelé" a tsz-központból, akkor általában akadt követô is a többi szomszédos faluban. Mindenütt jellemzô, ahol létrejött az ,,egy falu, egy szövetkezet" egység, hogy az új szervezet a faluszövetkezet nevet kapta. Az egyénileg kiválók száma csak Tolnában ( 827 fô), azon belül Dombóvár és Pincehely környékén volt jelentôs.

Ami a föld megmüvelését illeti, becslésem szerint az elkövetkezó egy-két évben a földterület $10-15$ százalékát fogják a magángazdák egyénileg mũvelni. A régión belül azonban e tekintetben nagy eltérések lesznek. A mezógazdaság átalakulásával kapcsolatos eddigi adatok arra engednek következtetni, hogy a magángazdaság csak Tolnában fog jelentôsen teret hódítani, Baranyában a tsz-ek stabilizálódni látszanak. Nagyon fontos tényezõ e megyében, hogy a vagyon több mint fele a ma ott dolgozó aktív tagok kezében van.

Ugyanakkor teljesen rejtélyes, hogy a kívülállók - akik között elvétve akad olyan, aki mezógazdasági vállal kozásba kezd - vagyonhányaduk nagy arányával, amely a Balaton-melléket jellemzi, mit fognak kezdeni? 


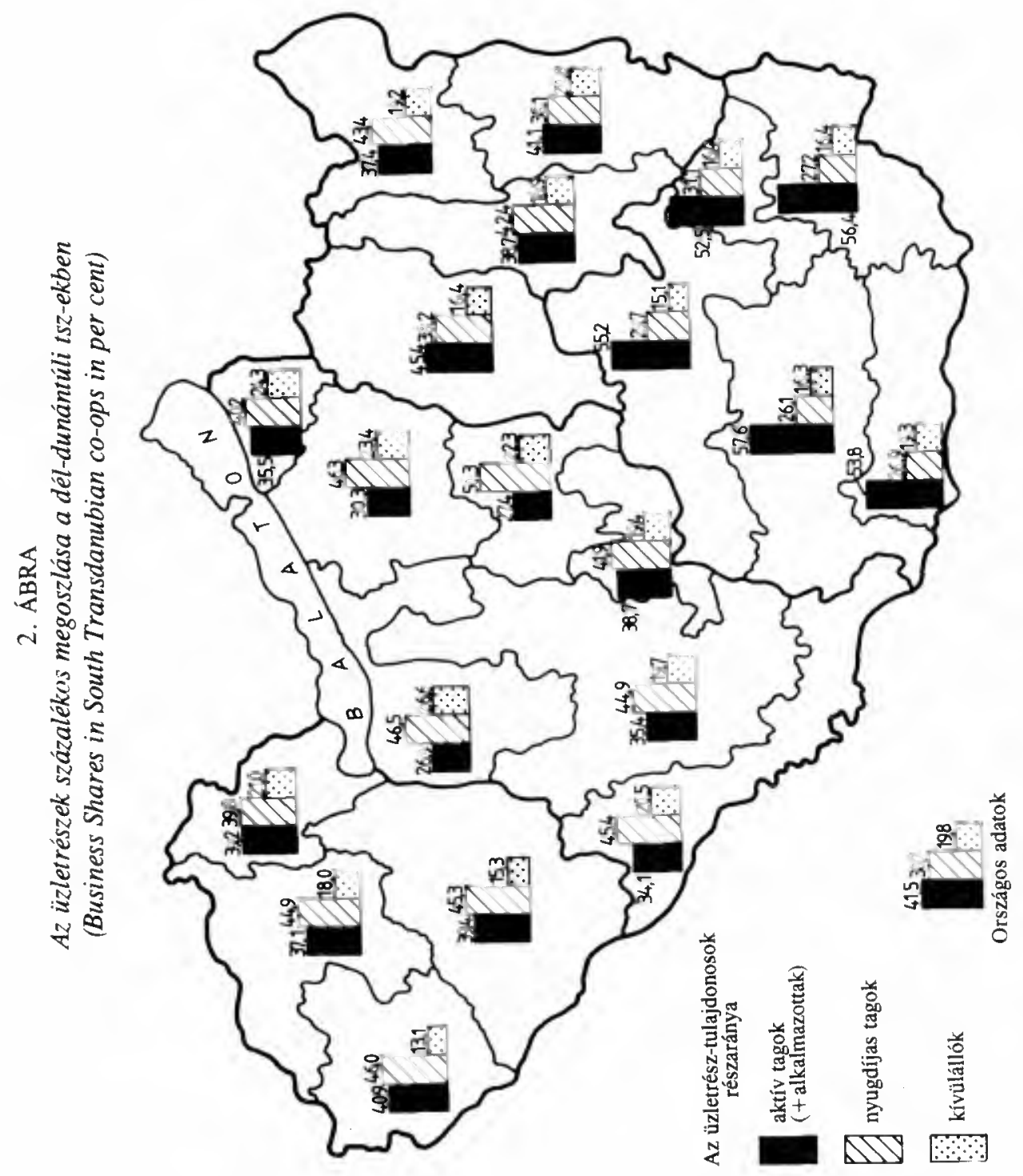




\section{TÁBLÁZAT}

A szövetkezetek vagyonának megoszlása az 1992. évi vagyonfelosztás után (országos adatok)

(Breakdown of the properties of the cooperatives following the property division of 1992 [national data])

\begin{tabular}{|c|c|c|c|c|}
\hline & \multicolumn{2}{|c|}{ A vagyonfelosztás } & \multicolumn{2}{|c|}{ A felosztott vagyon } \\
\hline & $\begin{array}{l}\text { során érintet- } \\
\text { tek száma } \\
\text { (ezer fố) }\end{array}$ & $\begin{array}{l}\text { során felosztott } \\
\text { vagyonérték } \\
\text { (Mrd Ft) }\end{array}$ & $\begin{array}{c}\text { egy főre jutó } \\
\text { értéke } \\
(1000 \mathrm{Ft}) \\
\end{array}$ & $\begin{array}{c}\text { \%-os megoszlása } \\
\text { a tulajdonosok } \\
\text { között }\end{array}$ \\
\hline $\begin{array}{l}\text { Szövetkezeti részjegy tulaj- } \\
\text { donosa összesen } \\
\text { Ebből: }\end{array}$ & 561,7 & 11,8 & 20,9 & 100,0 \\
\hline $\begin{array}{l}\text { - aktiv szövetkezeti tag } \\
\text { - nyugdíjas szövetkezeti tag }\end{array}$ & $\begin{array}{l}257,0 \\
304,7\end{array}$ & $\begin{array}{l}6,2 \\
5,6\end{array}$ & $\begin{array}{l}24,2 \\
18,1\end{array}$ & $\begin{array}{l}53,0 \\
47,0\end{array}$ \\
\hline $\begin{array}{l}\text { Szövetkezeti üzletrész tulaj- } \\
\text { donosa összesen } \\
\text { Ebbõl: }\end{array}$ & 1143,4 & 247,3 & 216,3 & 100,0 \\
\hline $\begin{array}{l}\text { - aktív szövetkezeti tag } \\
\text { - nyugdíjas szövetkezeti tag } \\
\text { - szövetkezeti alkalmazott } \\
\text { - kívülállók (volt tagok, örökö- }\end{array}$ & $\begin{array}{r}288,6 \\
350,7 \\
20,4\end{array}$ & $\begin{array}{r}100,4 \\
95,7 \\
2,3\end{array}$ & $\begin{array}{l}348,0 \\
272,8 \\
112,5\end{array}$ & $\begin{array}{r}40,6 \\
38,7 \\
0,9\end{array}$ \\
\hline seik, egyéb személyek) & 483,7 & 48,9 & 101,1 & 19,8 \\
\hline
\end{tabular}

Forrás: Varga Gyula (1993) A mezõgazdaság és a szövetkezetek átalakulása. Társadalmi Szemle 4, 35. o.

4. TÁBLÁZAT

A szövetkezetek vagyonának megoszlása az 1992. évi vagyonfelosztás után Baranya megyében

(Breakdown of the properties of the cooperatives following the property division of 1992 [Baranya county])

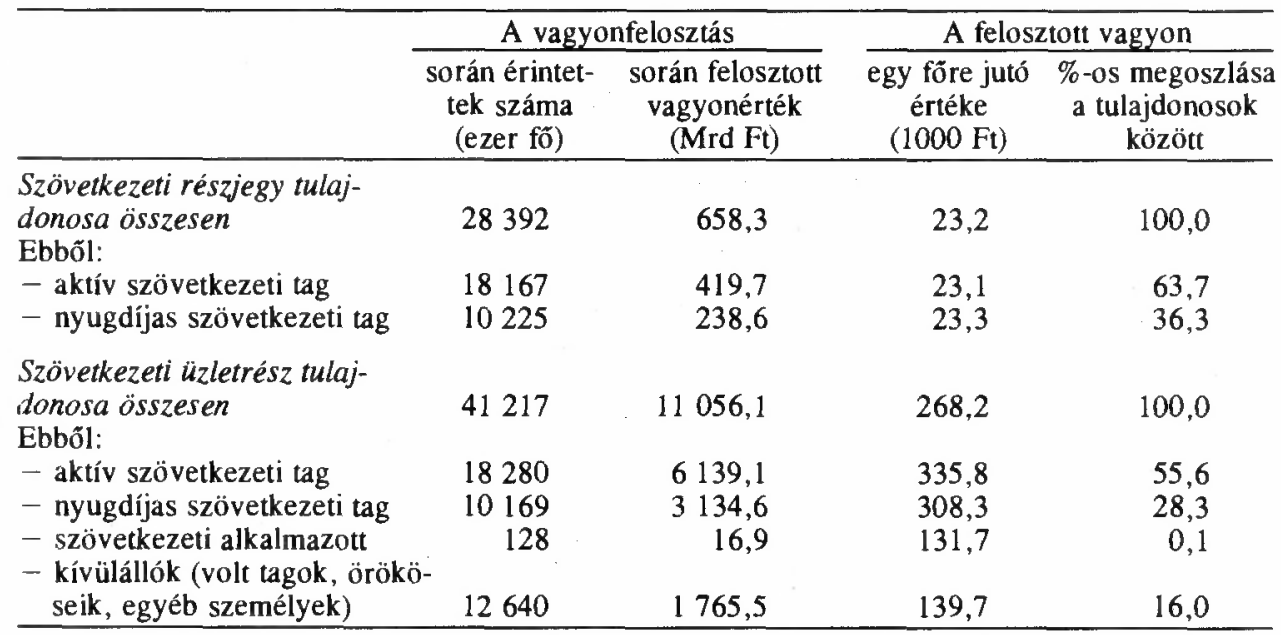

Forrás: a megyei FM-hivatalok, illetve Tolnában a MOSZ adatszolgáltatása alapján. 


\section{TÁBLÁZAT}

A szövetkezetek vagyonának megoszlása az 1992. évi vagyonfelosztás után Somogy megyében

(Breakdown of the properties of the cooperatives following the property division of 1992 [(Somogy county])

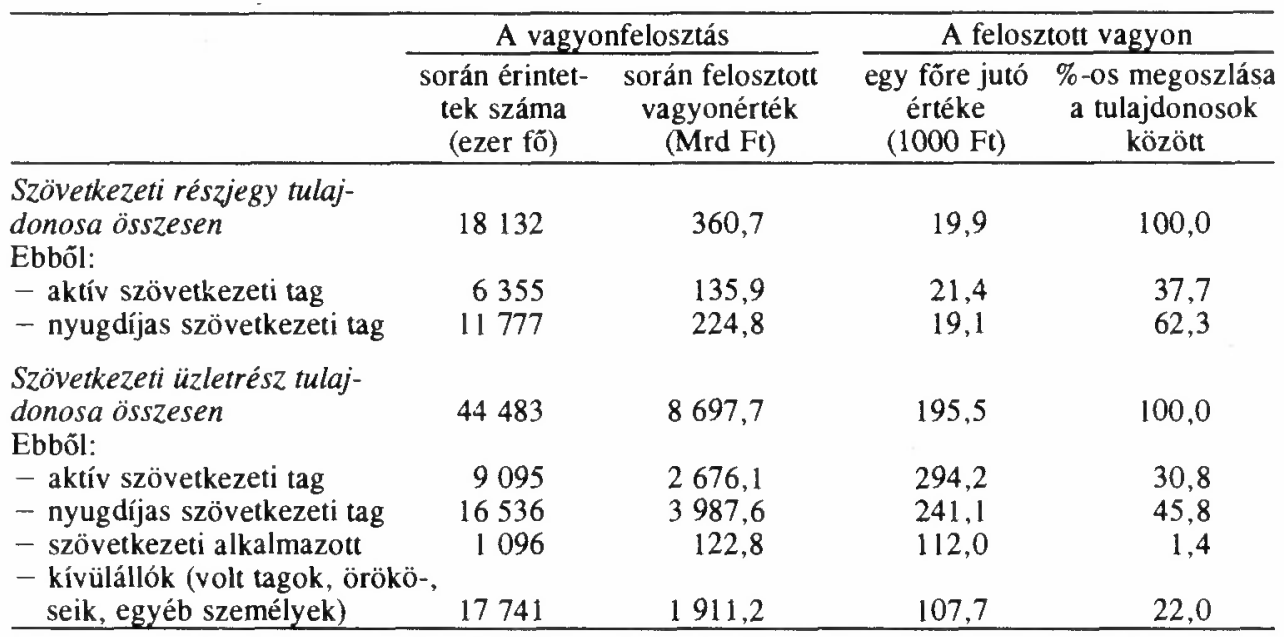

Forrás: a megyei FM-hivatalok, illetve Tolnában a MOSZ adatszolgáltatása alapján.

\section{TÁBLÁZAT}

A szövetkezetek vagyonának megoszlása az 1992. évi vagyonfelosztás után Zala megyében

(Breakdown of the properties of the cooperatives following the property division of 1992 (Zala county])

\begin{tabular}{|c|c|c|c|c|}
\hline & \multicolumn{2}{|c|}{ A vagyonfelosztás } & \multicolumn{2}{|c|}{ A felosztott vagyon } \\
\hline & $\begin{array}{l}\text { során érintet- } \\
\text { tek száma } \\
\text { (ezer fó) }\end{array}$ & $\begin{array}{l}\text { során felosztott } \\
\text { vagyonérték } \\
\text { (Mrd Ft) }\end{array}$ & $\begin{array}{l}\text { egy fóre jutó } \\
\text { értéke } \\
(1000 \mathrm{Ft})\end{array}$ & $\begin{array}{l}\text { \%-os megoszlása } \\
\text { a tulajdonosok } \\
\text { között }\end{array}$ \\
\hline $\begin{array}{l}\text { Szövetkezeti részjegy tulaj- } \\
\text { donosa összesen } \\
\text { Ebböl: }\end{array}$ & 15658 & 219,6 & 14,0 & 100,0 \\
\hline $\begin{array}{l}\text { - aktív szövetkezeti tag } \\
\text { - nyugdíjas szövetkezeti ta }\end{array}$ & $\begin{array}{r}5623 \\
\text { g } 10320\end{array}$ & $\begin{array}{r}83,4 \\
136,2\end{array}$ & $\begin{array}{l}14,8 \\
13,6\end{array}$ & $\begin{array}{l}37,0 \\
62,0\end{array}$ \\
\hline $\begin{array}{l}\text { Szövetkezeti üzletrész tulaj- } \\
\text { donosa összesen } \\
\text { Ebböl: }\end{array}$ & 29755 & 5496,6 & 187,5 & 100,0 \\
\hline - aktív szövetkezeti tag & 5899 & 2026,1 & 343,5 & 36,9 \\
\hline - nyugdíjas szövetkezeti tag & 11093 & 2447,5 & 220,6 & 44.5 \\
\hline $\begin{array}{l}\text { - szövetkezeti alkalmazott } \\
\text { - kívülállók (volt tagok, örć }\end{array}$ & $\begin{array}{l}1278 \\
\text { ököseik. }\end{array}$ & 123,8 & 96,8 & 2,2 \\
\hline egyéb személyek) & 11485 & 899,5 & 78,3 & 16,4 \\
\hline
\end{tabular}

Forrás: a megyei FM-hivatalok, illetve Tolnában a MOSZ adatszolgáltatása alapján. 


\section{TABBLAZAT \\ A szövetkezetek vagyonának megoszlása az 1992. évi vagyonfelosztás után Tolna megyében \\ (Breakdown of the properties of the cooperatives following the property division of 1992 [Tolna county])}

\begin{tabular}{|c|c|c|c|c|}
\hline & \multicolumn{2}{|c|}{ A vagyonfelosztás } & \multicolumn{2}{|c|}{ A felosztott vagyon } \\
\hline & $\begin{array}{l}\text { során érintet- } \\
\text { tek száma } \\
\text { (ezer fó) }\end{array}$ & $\begin{array}{l}\text { során felosztott } \\
\text { vagyonérték } \\
\text { (Mrd Ft) }\end{array}$ & $\begin{array}{l}\text { egy fôre jutó } \\
\text { értéke } \\
(1000 \mathrm{Ft})\end{array}$ & $\begin{array}{c}\text { \%-os megoszlása } \\
\text { a tulajdonosok } \\
\text { között }\end{array}$ \\
\hline $\begin{array}{l}\text { Szövetkezeti részjegy tulaj- } \\
\text { donosa összesen } \\
\text { Ebbôl: }\end{array}$ & 17947 & & & \\
\hline $\begin{array}{l}\text { - aktív szövetkezeti tag } \\
\text { - nyugdíjas szövetkezeti tag }\end{array}$ & $\begin{array}{l}8709 \\
9238\end{array}$ & & & \\
\hline $\begin{array}{l}\text { Szövetkezeti üzletrész tulaj- } \\
\text { donosa összesen } \\
\text { Ebbốl: }\end{array}$ & 32437 & 10032,0 & 309,3 & 100,0 \\
\hline - aktív szövetkezeti tag & 7563 & 4049,5 & 535,4 & 40,4 \\
\hline - nyugdíjas szövetkezeti tag & 9527 & 4069,3 & 427,1 & 40,5 \\
\hline $\begin{array}{l}\text { - szövetkezeti alkalmazott } \\
\text { - kívülállók (volt tagok, örö- } \\
\text { köseik, egyéb személyek) }\end{array}$ & 15347 & 1913,2 & 124,7 & - \\
\hline
\end{tabular}

Forrás: a megyei FM-hivatalok, illetve Tolnában a MOSZ adatszolgáltatása alapján.

\section{A szövetkezetek átalakulása}

Varga Gyula hivatkozott cikkében a szövetkezetek átalakulásának országos tendenciáját tömören a következốképpen összegzi: ,,Végsố soron a közeljövốben várhatóan az eddigivel csaknem azonos számú (tehát 1200-1400), de az eddigieknél jóval kevesebb embert foglalkoztató és kisebb területũ szövetkezet müködik majd az országban. Az átalakulások során az eddigi szövetkezetek 80 -90 százaléka (1100-1150) új típusú szövetkezetté válik és a szétválással, egy új szövetkezet megalakításával további, hozzávetốlegesen 200-300 új szövetkezet is létrejön. Gazdasági társaság is alakul majd, talán százegynéhány, részben $\mathrm{kft}$., részben részvénytársasági formában. Valószínũ, hogy 100-200 termelốszövetkezet viszont jogutód nélkül megszünik, nagyobb részt a vállalkozás csôdje, a gazdasági felszámolás következtében, és csak kisebb részben a 
tagok önkéntes elhatározása miatt. Nem becsülhetô fel azon szövetkezetek száma sem, amelyek átalakultak ugyan új szövetkezetté vagy gazdasági társasággá, de adósságterheik, likviditási gondjaik miatt nem tudják állni a következõ egy-két év súlyos terheit, s a felszámolás lesz a sorsuk" (Varga Gy. 1993, 41 o. o.).

A Dél-Dunántúl négy megyéjében az átalakulás elôtt 254 tsz volt. Ebböl elsố lépésben 288 különféle gazdálkodó szervezet keletkezett. A szövetkezetekben végbement változások irányát a Dél-Dunántúlon a 8 . táblázat szemlélteti.

\section{TÁBLÁZAT}

A szövetkezetekben végbement átalakulások a Dél-Dunántúlon (Transitions taking place in the cooperatives in South Transdanubia)

\begin{tabular}{|c|c|c|c|c|c|c|}
\hline \multirow{2}{*}{$\begin{array}{l}\text { A változás } \\
\text { megnevezése }\end{array}$} & \multirow[t]{2}{*}{ Baranya } & \multirow[t]{2}{*}{ Somogy } & \multirow[t]{2}{*}{ Tolna } & \multirow[t]{2}{*}{ Zala } & \multicolumn{2}{|c|}{ Összes egység } \\
\hline & & & & & száma & $\%$-а \\
\hline Részvénytársaság & - & 2 & 1 & 1 & 4 & 1,4 \\
\hline Kft. & 16 & - & - & - & 16 & 5,5 \\
\hline Holding & 1 & 3 & 4 & 2 & 10 & 3,5 \\
\hline \multicolumn{7}{|l|}{ Termelố- és szolgáltató } \\
\hline szövetkezetek & 54 & 20 & 48 & 29 & 151 & 52,4 \\
\hline Termelőszövetkezetek & 6 & 46 & - & 2 & 54 & 18,8 \\
\hline Egyéb szövetkezetek & 5 & 2 & - & 1 & 8 & 2,8 \\
\hline \multicolumn{7}{|l|}{ Várhatóan jogutỏd } \\
\hline nélkül megszūnik & 7 & 5 & 5 & 11 & 28 & 9,7 \\
\hline Nincs adat & - & - & 6 & 11 & 17 & 5,9 \\
\hline Összesen & 89 & 78 & 64 & 57 & 288 & 100,0 \\
\hline
\end{tabular}

Forrás: A megyei FM-hivatalok, illetve Tolnában a MOSZ adatszolgáltatása alapján.

Mint látható, a tsz-ek döntô többsége ún. új típusú szövetkezetté alakult. A korábbi tsz-ektôl ezek abban különböznek, hogy nincs közös tulajdonuk (ez a földre és az egyéb vagyontárgyakra is vonatkozik), továbbá, a vezetés nem az elnökség, hanem az igazgatóság kezében van. Az igazgatóság tagjai választott személyek élükön az igazgatóság elnökével. Legtöbb helyen a termelôszövetkezet név mellett feltüntetik még a szolgáltatást, jelezve ezzel, hogy ezt a tevékenységet is folytatni kívánják.

A termelô- és szolgáltató szövetkezet, valamint a termelôszövetkezet között a mai viszonyok között lényegében nincs különbség. Az egyéb szövetkezetek sorában van faluszövetkezet, tejszövetkezet, gazdaszövetkezet. Ezek általában kisebb egységek, amelyek a korábbi tsz-központból váltak ki, vagy egy településen belül váltak szét. Néhol már ,,visszaváltozás" is történt: a tsz-bôl holding lett, majd ismét visszaalakult szövetkezetté. Olyan esetben, amikor egy volt tsz jogutód nélkül megszũnt, előfordult, hogy belôle húszegynéhány szervezet alakult. Ezek között kft., termelôszövetkezet, szolgáltató 
szövetkezet is akad. Ez utóbbiban közös mũvelésben csak a termổterület maradt, a többi vagyon magánkézbe került.

A tsz-átalakulások még csak elkezdōdtek. Bizonyosra vehetô, hogy az elkövetkezó két-három évben fog befejezôdni ez a folyamat.

A nyolcvanas évek közepétõl jelentkezô, majd a rendszerváltással felgyorsuló gazdasági recesszió, a több éve tartó aszályos idöszak, a támogatások csökkenése, az agrárolló állandó nyílása és nem utolsó sorban a rendszerváltással együtt jelentkezõ általános elbizonytalanodás igencsak próbára tette a szövetkezetek gazdálkodását és anyagi helyzetét. Ennek ellenére a mezôgazdasági termelés fỗ volumenét az elkövetkezõ öt-tíz évben az átalakult tsz-ek fogják biztosítani.

\section{A kárpótlás}

A átalakulás elốtt a tsz-földek 36 százaléka a részarány-tulajdonosok kezében volt. 61 százalékot tett ki a közös szövetkezeti tulajdonú földek aránya, 3 százalék állami tulajdonban volt. A részarány-tulajdonosok döntố része tsz-nyugadijas, kisebb része kívülálló vagy aktív tsz-tag.

Az ország közel 1,5 millió részarány-tulajdonosának csak 14,1\%-a található a négy dél-dunántúli megyében. Somogyban a tsz-nyugdíjasok nagy aránya hozzájárult ahhoz, hogy a megye az ,,országos listán" középen helyezkedjen el, a másik három megye azonban az országos átlag alatt van. Ha nem aranykoronában, hanem hektárban vizsgáljuk az adatokat, akkor Zala megye kissé jobb helyzetbe kerül. Ez annak tudható be, hogy a részarány-tulajdonosok is jelentốs erdốterülettel rendelkeznek, aminek alacsony az aranykorona-értéke. A részarány-tulajdonosok földjeinek a kijelölése folyamatban van, ami - az eddigi igények alapján - nem fogja jelentôsen csökkenteni az átalakult tsz-ek mũvelésében lévô területeket. Baranyában pl. a 85556 részarány-tulajdonos közül 67401 -en adták be földkijelölési igényüket, de 1994 júniusáig mindössze 6733 jogerốs határozat született. (Nyilván ôk sürgették legjobban földjeik kiadását.) A többi igényrốl még ezután döntenek a földkiadó bizottságok.

A kárpótlási törvények kihatása jelentôsebb lesz a magántulajdonosi réteg megteremtése szempontjából, mint a szövetkezeti átalakulási törvény és az ahhoz kapcsolódó átmeneti szabályok. Míg a tsz-ek esetében a volt közös tulajdonnak a megszünése és a tényleges tulajdonnal bíró tagok megjelenése éppen csak, hogy elkezdôdött, addig a kárpótlási folyamat során megszerzett földeknél a tényleges magántulajdon kialakulása egy-egy árverés befejeztével megtörtént. Az elsố kárpótlási törvény az egykori tulajdonosokat, illetve azok leszármazottait, továbbá a tsz-ben dolgozó, de ma föld nélkül lévô tagokat egy jelképes, 1,5 hektáros területtel kívánta földhöz juttatni.

Az idôközben meghozott harmadik kárpótlási törvénybe - az ,EÉletüktôl és szabadságuktól politikai okokból jogtalanul megfosztottak kárpótlása" - azt is belevették, hogy 
a volt politikai üldözöttek kárpótlási jegyein is lehessen földet vásárolni. Ezáltal már nemcsak az egykori tulajdonosok számára nyílt meg a földszerzés lehetôsége. Bár a politikai okokból kárpótoltak közül kevesen vettek földet, de eladták kárpótlási jegyeiket, többek között olyanoknak, akik földet akartak vásárolni, ezért az õ kárpótlási jegyeik egy része is földvásárlásra fordítódott. Ezzel egyidôben a mai tulajdonosok sorába olyanok léptek be, akik valaha nem voltak tulajdonosok. Az egykori tulajdonosok részérôl nem volt nagy a földvásárlás iránti érdeklôdés, illetve, az ország különbözõ területein már a törvény meghozatalától kezdõdõen nagyon eltérố igény nyilvánul meg a kárpótlás iránt.

A kárpótlási igények bejelentése után a helyi kárrendezési hivatalok - a föld minôségét kifejezõ, úgynevezett aranykorona-értékben - közölték a tsz-eknek és az állami gazdaságoknak a kezelésében lévô földekre vonatkozó földigényt.

A Dél-Dunántúl már a beadott kárpótlási igények alapján hátránnyal indult. Míg az összes termốterület 19,2 százaléka, addig a kárpótlási igények 16,2 százaléka esik erre a régióra. A Dél-Dunántúl azonban a kárpótlási igények bejelentésekor sem egységes. Tolna a maga hárommillió aranykoronán felüli igényével a legerôsebb megyék közé került az országban. Somogy ugyan a 12. helyen van, de a beadott kárpótlási igények alapján helyzete közepesnek mondható. Baranya a 16., Zala pedig az utolsó, 19. helyet foglalja el a megyei kárpótlási igények rangsora tekintetében.

Tolnában - többek között - azért volt nagy a kárpótlás iránti érdeklôdés, mert Békés és Fejér megyékkel együtt ebben a megyében vannak a legjobb minôségũ földek.

Zalában és Baranyában a kárpótlás kezdetekor kicsik voltak az igények, mert ezek aprófalvas településszerkezetũ térségek, ahonnan az 1960-as évektôl kezdôdốen elköltözött a lakosság szorgalmasabb és jobb képességekkel rendelkezô része, amely ma már oda földvásárlás céljából sem kíván visszamenni. Baranyában az egykori lakosság egyharmadát kitevố németség kárpótlási igényét csak a második kárpótlási törvény meghozatala után tudták kimutatni. A második kárpótlás alkalmával Baranyában 12,8 ezer, Tolnában 5,7 ezer, Somogyban 2,2 ezer és Zalában 0,9 ezer igény érkezett a megyei kárpótlási és kárrendezési hivatalokhoz.

Zala erdôs térség, ott van az ország erdốterületének 10,1 százaléka, és az országnak ebben a megyéjében árverezték el a legtöbb erdôterületet. Az erdôknek pedig köztudot$\tan$ alacsony az aranykorona-értéke. (1 ha erdõ átlagosan 2 AK-értéket tesz ki). A kárpótlási igény nyilván arányosan merült fel az erdốk irảnt is, ami hozzájárult ahhoz, hogy Zalában az aranykoronában mért kárpótlási igény alacsonynak túnik.

A kárpótlási igénybejelentések után kezdôdtek a földalap-kijelölësek. A tsz-ekben négy alapot különítettek el: 1. részarány-tulajdonosok földalapja, 2. tagok és alkalmazottak (30, illetve $20 \mathrm{AK}-\mathrm{s}$ ) alapja, 3. kárpótlási földalap, és 4. állami földalap. Az állami gazdaságoknál az elsô földalap kivételével és azzal a különbséggel, hogy ốk csak 20-20 aranykoronát juttathattak alkalmazottaiknak, ugyanezek a földalapok voltak érvényben. 
Ha tsz-ek eleget tettek volna a kárrendezési hivatalok közlésének, akkor országosan a volt közös földterületük 71 százalékát jelölték volna ki kárpótlásra. Ezzel szemben a volt közös földterületeknek 53 százaléka lett kijelölve kárpótlásra. A különbözetnek három forrása van. Az elsố a föld nélküli tagok és alkalmazottak 30, illetve 20 aranykoronája, ez a volt közös földterület 24 százalékát teszi ki. A második ok az, hogy az átmeneti törvény lehetôvé tette, hogy a vagyonnevesítés arányában szétosszák a kárpótolt és föld nélküli tagok része után fennmaradt közös tulajdonú földeket a mostani tsz-tagok között, amit minden tsz-ben meg is tettek. Végül néhány helyen még mindig nincsenek jogerósen jóváhagyott földkijelölések.

Egész Kelet-Közép-Európában egyedülálló az a magyar megoldás, ahogy a volt tulajdonosok földhöz jutnak. Ennek módja a földvásárlás. Az árverések 1992. augusztus 20. után kezdõdtek, 1994. február 28-ig országosan az elsõ kárpótlás alkalmával bejelentett igények kétharmadát kielégítették.

Az 1994. február 28-ig elvégzett földárverési eredmények alapjản megállapítható, hogy a Dél-Dunántúl 1567470 ha termôterületébôl 263330 ha-t ${ }^{3}$ adtak el a kárpótlás folyamán. Tehát a fenti idôpontig a termóterület 16,8\%-a került a kárpótoltak kezébe (9. táblázat). Ezzel a régióban az elsô kárpótlási törvény életbelépésekor bejelentett aranykorona-igények $60 \%$-át kielégítették, de míg ez az arány Baranya, Zala és Tolna megyében több mint 70 , addig Somogyban mindössze $36 \%$. Jelenleg nem tudni, hogy Somogyban vajon ezután gyorsul fel a földvásárlás, vagy az emberek ebben a megyében nem kívánnak élni a földkárpótlás lehetõségével?

\section{TÁBLÁZAT}

Az árveréseken eladott földek aránya a Dél-Dunántúlon (1994. február 28.) (Rate of the lands sold in auctions in South Transdanubia [February 28. 1994])

\begin{tabular}{lcccrrr}
\hline Megyék & $\begin{array}{c}\text { A kárpótlási } \\
\text { földterületek } \\
\text { aránya a termô- } \\
\text { területen } \\
\text { belül (\%-ban) }\end{array}$ & $\begin{array}{c}\text { A tulajdon- } \\
\text { szerzésben } \\
\text { résztvevôk } \\
\text { száma }\end{array}$ & $\begin{array}{c}\text { A megszerzett } \\
\text { fóldterület } \\
\text { átlaga (ha) }\end{array}$ & \multicolumn{2}{c}{$\begin{array}{c}\text { A megszerzetı földek } \\
\text { ha }\end{array}$} & AK \\
\hline Baranya & 15,6 & 14735 & 4,0 & 59601 & 973184 \\
Somogy & 12,1 & 10200 & 5,8 & 59507 & 868677 \\
Tolna & 32,3 & 16253 & 6,2 & 100693 & 2202662 \\
Zala & 11,4 & 23503 & 1,9 & 43529 & 561147 \\
Dél-Dunántúl & 16,7 & 64691 & 4,1 & 263330 & 4605670 \\
\hline
\end{tabular}

Forrás: árverési jegyzôkönyvek alapján a szerzō saját számítása. 
Baranya, Somogy és Zala között nincs nagy különbség a megszerzett kárpótlási földterületek termôterületen belüli - hektárban számított - arányát illetổen. Ez az arány a 11,4-15,6\% között mozog. Ezzel szemben Tolnában a termốterületek egyharmada került magánkézbe a kárpótlás révén. Bár a pótkárpótlás okozhat még meglepetéseket, mégis Tolnában, Baranyában és Zalában a földárverések a befejezéshez közelednek, és várhatóan csupán további 5-10\%-kal emelkedik a kárpótlási földek termôterületen belüli aránya. Ez Somogy megye esetében is előfordulhat, de hasonló esély van arra, hogy ott a kárpótolt földek aránya akár további $15-20 \%$-kal is növekedjen még.

Az elárverezett aranykorona-értékek alapján az összes megye rangsorában Tolna az elôkelố harmadik helyet foglalja el, csak Békés és Jász-Nagykun-Szolnok megye elôzi meg. Baranya a 13., Somogy a 14., Zala pedig az utolsó elôtti, 18. helyet foglalja el.

Az elárverezett aranykorona-értékek tekintetében 1993 közepén még nagy területi különbségek voltak az egyes dél-dunántúli megyék tájkörzetein belül. Napjainkra másfél évvel az árverések megkezdése után - ezek a megyén belüli különbségek csökkentek, de a megyék közötti különbségek jelentôsek maradtak (3. ábra). A régióban eladott 4,6 millió aranykorona értékũ föld $48 \%$-át Tolnában vették meg. Ott a legmagasabb az földterületek átlagos nagysága (6,2 ha). Ez az átlag az egy-egy árverésen megszerzett földterületre vonatkozik. Egy személy azonban rendszerint több árverésen is vásárol földet, így egy család által átlagosan megszerzett földterület ténylegesen ennek a duplája lehet.

1994. február 28-ig a kárpótlás révén földtulajdonhoz jutottak száma a négy megyei kárpótlási és kárrendezési hivatal adatai alapján 64 691. A valóságban ezt az adatot hasonlóan kell kezelnünk, mint az átlagos földterületre vonatkozót azaz, mivel egy-egy személy kétszer vagy akár többször is megjelent a földárveréseken, ezért a fenti számot kettôvel lehet elosztani, következésképpen, a dél-dunántúli régióban $\mathrm{kb}$. 30 ezer ember vásárolt kárpótlási földet. Sajátos e tekintetben Zala megye, ahol mind aranykoronában, mind hektárban kifejezve, a legkevesebb föld kelt el, ugyanakkor a legtöbb földtulajdonos éppen ebben a megyében keletkezett. Zalában az emberek egy-egy kisebb darab földet vettek maguknak, miközben a földterületeknek (hektárban számítva) $25 \%$-a erdó volt (10. táblázat).

A kárpótlásként eladott erdốk aránya az össz erdôterületen belül kisebb, mint a kárpótlási szántóterületnek az összes szántóterületen belüli aránya.

A kárpótlás igénye a városok és ezen belül is a megyeközpontok határában a legnagyobb. Ilyen helyeken nagy méretũ földfelaprózódás tapasztalható A megyei kárpótlási és kárrendezési hivatalok adatai alapján a megszerzett földterületek átlaga Pécsett 0,3 , Zalaegerszegen 0,6, Kaposváron 1,0, és Szekszárdon 2,2 ha.

A városokon kívül csupán a jó minốségũ földekkel rendelkezô térségek voltak vonzóak a földvásárlások számára, de sem az üdülökörzetekben (pl. a Balaton mellékén), sem az osztrák határ mentén a tájkörzetek szintjén nem növekedett meg jelentôsen a kárpótlási földek termôterületen belüli aránya. Ugyanakkor a horvát határ közelében is 
Kovács Teréz: A mezőgazdaság privatizációja a dél-dunántúli régióban.

Tér és Társadalom, 8. 1994. 1-2. 109-128. p.
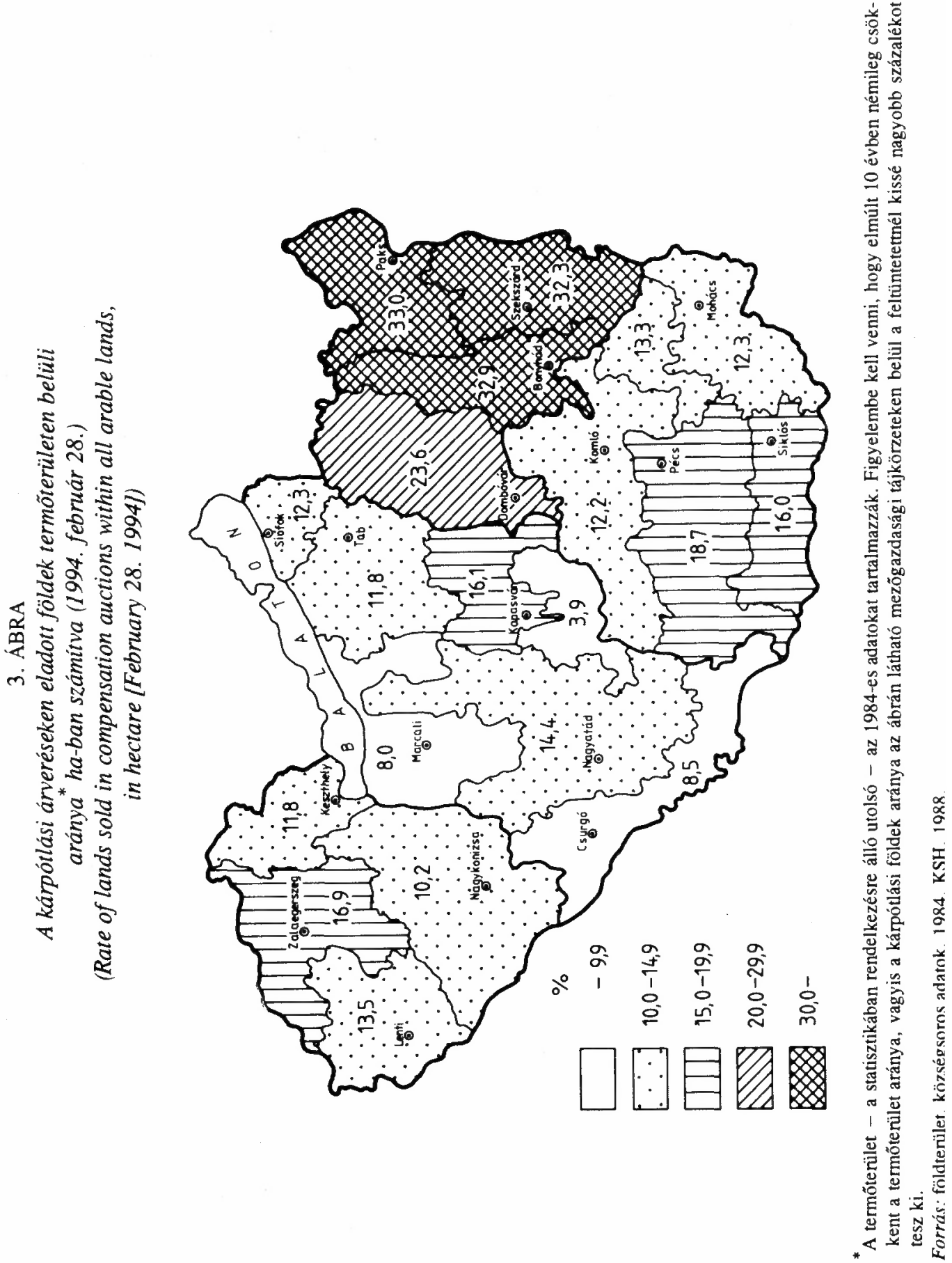


\section{TÁBLÁZAT}

Az erdóterületek kárpótlása (1994. február 28.)

(Compensation of the forest areas [February 28. 1994])

\begin{tabular}{lccccc}
\hline Megyék & $\begin{array}{c}\text { Az erdố aránya } \\
\text { az össz- } \\
\text { területen } \\
\text { belül }(\%)\end{array}$ & $\begin{array}{c}\text { Az összes } \\
\text { erdốterület } \\
\text { (ha) }\end{array}$ & \multicolumn{3}{c}{ Ebböl kárpótlásként eladott terület } \\
\cline { 5 - 6 } & 23 & 103262 & 7561 & $\%$ & AK \\
\hline Baranya & 25 & 151194 & 8848 & 7,3 & 16570 \\
Somogy & 14 & 52248 & 9198 & 17,6 & 43047 \\
Tolna & $41^{*}$ & $172707^{*}$ & 10710 & $6,2 * *$ & 46891 \\
Zala & 27 & 479411 & 36717 & 7,6 & 128713 \\
Összesen & 23 & & & &
\end{tabular}

A Balatonfelvidéki Erdổ- és Fafeldolgozó Gazdaság Rt. összes erdõterülete 66593 ha. Ennek csupán 15\%-a (10 040 ha) van Zala megyében, 56355 ha Veszprém és 198 ha Gyõr-Moson-Sopron megyében. $\mathrm{Az}$ rt. székhelye Keszthelyen található, de - függetlenül attól, hogy területeinek döntô része más megyékben van - a Statisztikai Évkönyvben az egész területet Zalánál vezetik. Ha a valóságnak megfelelô * adatokat vesszük, akkor Zalában összesen 116154 ha erdõ van, ami a régió szintjén 31\%-ot teszi ki.

"Ha a ténylegesen Zalában található erdõket vesszük alapul, akkor megállapítható, hogy ebben a megyében az erdôterületek 9,2\%-a, a régióban pedig $8,7 \%$-a került a kárpótoltak kezébe.

Forrás: A megyei kárpótlási és kárrendezési hivatalok árverési jegyzổkönyvei.

megindult az érdeklôdés a földvásárlás iránt, a régiónak ez a része hamarosan leküzdi a kárpótlás elsõ évében észlelt hátrányát.

A megyeszékhelyek (és a többi város) határában jórészt befektetési céllal történtek a földvásárlások. A kárpótlási földek alacsony ára ugyanis földvásárlásra késztette nemcsak a föld-, hanem a hảz- és a vállalkozási kárpótlási jegyekkel rendelkezôket is. E vásárlók jártasak a piaci viszonyokban, és azzal számolnak, hogy mielótt az EK teljes jogú tagjai leszünk, a földárak megnövekednek, ôk pedig jelentõs tõkével fognak rendelkezni mostani befektetésük eredményeként. Ezek a befektetôk általában a helyi nagyüzemmel mũveltetik földjeiket, ezért jelenleg nem szembetũnố a nagyvárosok határában tapasztalható ésszerütlen földfelaprózódás. Ennek ellenére olyan intézkedések szükségesek, amelyek elốsegítik a kis parcellák egyesítését. Elsổ lépésben lehetôséget kellene teremteni az ingyenes tagosításra azok számára, akik maguk mũvelik földjeiket, a szomszédok kölcsönös megegyezése alapján. Második lépésben ajánlatos lenne mentesíteni a illeték megfizetése alól azokat, akik a sajăt földjük melletti parcellát kívánják megvenni.

Örvendetesnek mondható, hogy az utóbbi idổben megindult az érdeklôdés a kárpótlási földvásárlás iránt a rossz termổhelyi adottságú térségekben is, mint pl. az Ormánságban és a Somogyi-homokvidéken. Elốször is az ilyen térségekben lenne ajánlatos - legalább a kárpótlási földeken - a termelési szerkezetet módosítani. Olyan termelési szerkezetet kellene kialakítani, amely a rossz termốhelyi körülmények között is gazdaságos ter- 
melést biztosít (pl. húshasznosítású tehéntartás). Emellett támogatást szükséges nyújtani a nagy munkanélküliséggel küszködô mezôgazdasági térségeknek. E cél elérése érdekében vissza nem térítendô, a termelés beindítását támogató, illetve kedvezményes kamatozású hosszú lejáratú hiteleket kívánatos nyújtani abban az esetben, ha bizonyított a termék piaci értékesítése. Elsôsorban a kis befektetést igénylő, kézi munkaigényes, házi készítésũ (pl. zöld- és farmturizmust szolgáló), illetve a külföldi alapanyagot helyettesítô termékek elôállitását célszerũ támogatni (pl. dohány-, lucernatermesztés).

A régióban a farmergazdálkodásra alkalmas középbirtokok nagyobb számban csak Tolnában jelennek meg. Baranyảban és Somogyban ritkán, Zalában pedig nagyon elvẻtve fordulnak majd elõ.

\section{Jegyzetek}

1 A tájgazdálkodás alapjai (1992). 17 o.

2 A szövetkezetek átalakulásával kapcsolatos adatok a megyei FM-hivatalok (illetve Tolnában a MOSZ) általunk megrendelt adatszolgáltatásai alapján kerültek összegezésre. Az adatok általában nem teljes körũek. A tanulmányban a legfrissebb összesített kárpótlási adatok szerepelnek, amelyekhez a megyei kárpótlási és kárrendezési hivatalok árverési jegyzôkönyvei alapján jutottunk. Az adatokat településsorosan gyũjtöttük össze, majd a mezőgazdasági tájkörzetek szintjén mutattuk ki. Az adatok teljes körũek.

\section{Irodalom}

A tájgazdálkodás alapjai. Az agroökológiai potenciálra alapozott tájkörzetek és távlati termelési irányaik. I-II. kötet. FM, Budapest, 1992.

Csete L. (1992) Fó- és mellékfoglalkozású magángazdálkodók 1993. évi helyzete és kilátásai. Gazdálkodás, 2. $1-19.0$.

Deli L.-Sibinger M. (1991) A gazdasági rendszerváltás útja és lehetôségei a mezốgazdaságban. BKE Közgazdasági Továbbképzõ Intézet, Budapest.

Fekete P. Gy. (1994) Az Európai Unió agrárpolitikai reformjának várható hatásai. Gazdálkodás, 1. 34-49. o. Hantó Zs. (1994) A mezőgazdasági privatizáció társadaimi következményei. Gazdálkodás, 1. 39-49. 0.

Jussila, H. - Häkkilä, M.-Malinen, P. (1993) Finland's National Rural Policy Facing the Challange of European Integration. Research Institute of Northern Finland University of Oulu, Oulu.

Kovács T. (szerk. 1993) Kiút a valságból. II. Falukonferencia. MTA RKK, Pécs.

Laczó F. (1994) A tulajdonszerkezet változása a mezõgazdaságban. Gazdálkodás, 3. 1-12. o.

Láng I. - Csete L. (1992) Az alkalmazkodó mezógazdaság. AGRICULA, Budapest.

Somogyi S. (1994) A regionális fejlesztés, menedzserképzés és az agrárszempontok. Gazdálkodás, I. $57-62$. 0 .

Szelényi I. (1992) Harmadik út? Polgárosodás a vidéki Magyarországon. Akadémiai Kiadó, Budapest.

Varga Gy. (1993) A mezôgazdaság és a szövetkezetek átalakulása. Társadalmi Szemle, 4. 32-41. o. 


\section{PRIVATISATION OF THE AGRICULTURE IN THE SOUTHERN TRANSDANUBIAN REGION}

\section{TERÉZ KOVÁCS}

Between 1990 and 1992, together with the decrease of the agricultural population, the number of agricultural workers dropped by a third in Southern Transdanubia. Currently in Tolna and Somogy, every fifth, in Zala every seventh, and in Baranya every eighth person lives on agriculture.

The privatisation of agriculture is more advanced in Hungary than that of industry, but this process has not been completed yet, either.

An important point of the process was the so-called co-operative personalisation that took place in 1992. Then all properties, except land were evaluated and the property was personalised based on different principles, such as years worked, amount of the income, and the value of the property taken into the co-operative in 1960. This meant that every person was told how much his or her share of the total property of the cooperative was worth. So they did not say that "this tractor is yours" but that "X amount of the total property of the co-operative is yours". If somebody still wanted to get his or her property in kind, he or she had to announce it in a certain time, he or she got his or her property but also lost his or her job, i. e. he or she had to resign from the co-operative. A very few used this opportunity. The property was divided among the present active members, the pensioners of the co-operative and those who had worked at least 5 years there, in the case of their deaths their descendants obtained the property, but only if they handed in their application by a certain time. These were called outsiders, at national level $20 \%$ of the property belongs to them, $39 \%$ to the pensioners and $41 \%$ to the active members. The active members received the largest amount of property in Baranya.

Following this, the obligatory transformation of the co-operatives took place. Most of the co-operatives (appr. 70) "transformed" into the same thing it had been before, i. e. a co-operative. Almost $10 \%$ of them are eliminated without a legal successor. The others were divided into smaller co-operatives, or go on functioning as Ltd.-s or Inc.-s.

The privatisation of the land was an even more complicated process. In Hungary, unlike the other socialist countries, the land was not given back to the original owners. Still, if somebody had been deprived of land, he or she could get (following a long and slow process) a piece of land the value of which was the same as his or hers, but not the same that had been taken away. This procedure was called compensation.

In Southern Transdanubia, the lands marked for compensation consisted $16.7 \%$ of the total area (datum of 28 . Feb. 1994). This will grow by another 5-10\%. Approximately half of these lands are tilled by private persons, on the other half the co-operatives work, for extremely low wages. The compensated areas amount to one third of the total area in Tolna, the farmer economies are the most wide-spread in that county. 